\title{
Hyalolithus tumescens sp. nov., a siliceous scale-bearing haptophyte from the middle Eocene
}

\author{
Kenta Abe ${ }^{1}$, Hideto Tsutsui ${ }^{2}$ \& Richard W. Jordan ${ }^{3 *}$ \\ ${ }^{1}$ Graduate School of Science and Engineering, Yamagata University, 1-4-12 Kojirakawa-machi, Yamagata 990-8560, Japan \\ ${ }^{2}$ Department of Biology, Faculty of Science, Yamagata University, 1-4-12 Kojirakawa-machi, Yamagata 990-8560, Japan \\ ${ }^{3}$ Department of Earth \& Environmental Sciences, Faculty of Science, Yamagata University, 1-4-12 Kojirakawa-machi, \\ Yamagata 990-8560, Japan \\ *Correspondence: sh081@kdw.kj.yamagata-u.ac.jp
}

\begin{abstract}
Siliceous scales resembling those of the living haptophyte Hyalolithus neolepis Yoshida et al. were discovered in middle Eocene outcrop sediments from the Kellogg Shale in California, and Chalky Mount and Springfield in Barbados. Like $H$. neolepis, the fossil scales have a marginal rim, hyaline margin and numerous openings in the central area. However, they differ in the nature of the pit-like depression on the distal surface and the corresponding swelling on the proximal surface. Such swellings are very rare in $H$. neolepis and were not part of the original description. The presence of a swelling on all fossil scales found so far is sufficient enough to warrant the erection of $H$. tumescens Abe, Tsutsui \& Jordan sp. nov. These findings represent the oldest known fossil record of the Prymnesiales.
\end{abstract}

Keywords: Eocene, Haptophyta, Hyalolithus, Prymnesiales, siliceous microfossils

Received 6 July 2015; accepted 20 December 2015

In seawater samples, most siliceous scaly organisms belong to the Chrysophyceae, Parmales, Prasinophyceae, Heliozoa, Thaumatomastigidae or testate amoebae. On the other hand, their calcareous counterparts belong almost exclusively to the haptophytes, which possess coccoliths and/or unmineralized organic scales. Thus, it was quite unexpected when a molecular genetic analysis and ultrastructural study revealed that Hyalolithus neolepis Yoshida et al. was a siliceous scaly haptophyte (Yoshida et al. 2006). The cell is covered by numerous overlapping siliceous scales; thin perforated plates with two central mounds and a marginal rim on the distal side (Yoshida et al. 2006; Patil et al. 2014; Jordan et al. 2016). The plates appear solid, not hollow like the skeletons of silicoflagellates (Fig. 1). The species appears to have a low morphological diversity in temperate-tropical waters of both hemispheres, being found in coastal and open ocean settings (Jordan et al. 2016). Genetic analysis of H. neolepis placed it among species of Prymnesium Massart, leading to its transfer to the latter genus (Edvardsen et al. 2011). However, the Prymnesium clade is morphologically heterogeneous and, at present, H. neolepis is the only member of the Prymnesiales that has siliceous scales in the non-motile phase - although silica has been detected in the outer scale covering of non-motile cysts of Prymnesium parvum (Pienaar 1980; Green et al. 1982), and scales of P. polylepis are known to contain silicate (Edvardsen et al. 2011). However, the siliceous material is deposited only on the distal side of the organic scale and is therefore not equivalent to the completely silicified scale of Hyalolithus. Thus, in this paper we have retained the original name, Hyalolithus neolepis. Another possible siliceous haptophyte is the enigmatic Petasaria heterolepis Moestrup (Moestrup 1979; Patil et al. 2015; Jordan et al. 2016), but concrete evidence, such as the possession of a haptonema or molecular sequences from cultures, is still lacking.

Since the siliceous scales of the enigmatic microfossil Macrora Hanna (possibly related to the filose amoeba Pinaciophora Greeff) are preserved in Palaeogene and Neogene marine sediments, it raises the question, could siliceous haptophyte scales have a similarly long fossil record? During routine surveys of outcrop and deep-sea drilling materials of Eocene age, siliceous scales resembling Hyalolithus were encountered. Herein the scales are compared with those of living Hyalolithus and the implications of this find are discussed.

\section{Material and methods}

In this study a number of middle Eocene samples were investigated, but only those below yielded fossil Hyalolithus-like scales. Details on the collection and preparation of the Seto-29 sample, used in Figure 1, can be found in Abe et al. (2015).

- Chalky Mount, Barbados (Hustedt Diatom Collection access number AM22A) - provided by Friedel Hinz (previously at the Alfred-Wegener-Institute, Bremerhaven).

- Springfield, Barbados - provided by Frithjof Sterrenburg.

- Kellogg Shale, California (CD-11 and K5) - provided by John Barron (USGS, Menlo Park); for more details on these samples see Barron et al. (1984).

A small amount of raw sample was prepared as a suspension in distilled water, some of which was filtered on to a Millipore HAtype nitrocellulose filter ( $47 \mathrm{~mm}$ diameter, $0.45 \mu \mathrm{m}$ porosity). The filter was then air-dried and stored in a plastic petrislide. A portion of the filter $(6 \times 6 \mathrm{~mm})$ was cut out, mounted on to an aluminium scanning electron microscope (SEM) stub and coated with $\mathrm{Pt} / \mathrm{Pd}$ in an Eiko IB-3 ion coater. The stubs were then observed in a JEOL JSM-6510LV SEM and digital images taken using the built-in camera system.

For light microscope (LM) permanent mounts, a portion of the suspension was pipetted on to a cover slip covered in distilled water and dried on a hot plate. Three drops of Mountmedia ${ }^{\circledR}$ (Wako Pure Chemical Industries, Ltd.; refractive index $=1.50$ ) were pipetted on to a glass slide and the cover slip was then inverted and placed on top. The slide was then held over a hot plate until the mounting medium had stopped bubbling, after which it was removed from the 

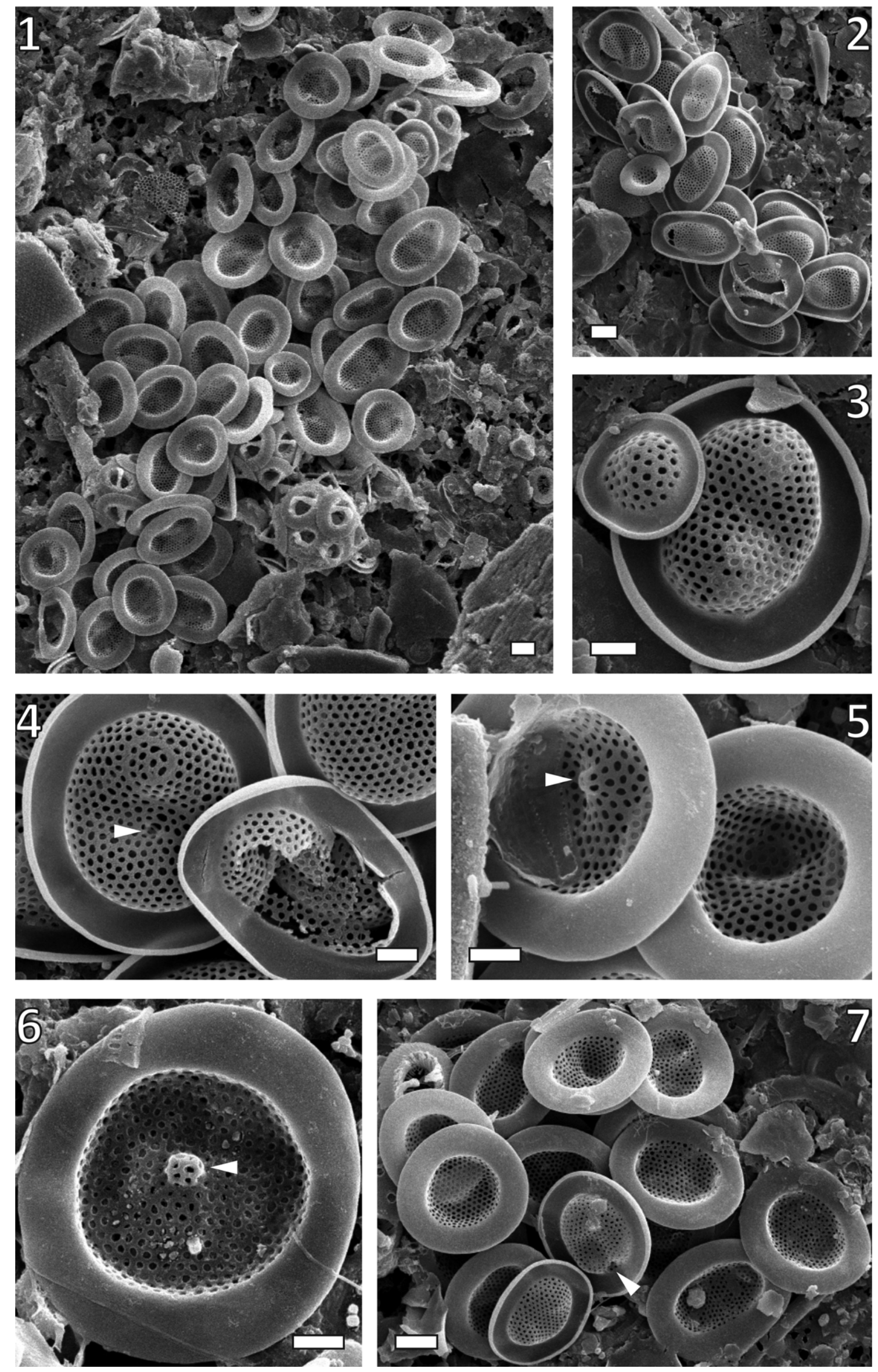
heat and left to cool down. At this time a label was added Permanent mounts were observed on an Olympus BX40 with an oil immersion objective lens and phase contrast illumination at $\times 1000$ magnification. Micrographs were taken with a Canon EOS Kiss X6i camera, attached to the microscope, with a type NY1S relay lens (Micronet Co., Ltd). Locations of the holotype and paratype were recorded with an England Finder (acquired from SPI Supplies, Structure Probe Inc., USA).

\section{Systematic description}

The new species is described below from the middle Eocene sediments of Barbados and California and compared with the type species, Hyalolithus neolepis, which has been described elsewhere (Yoshida et al. 2006; Patil et al. 2014; Jordan et al. 2016).

Class Prymnesiophyceae Hibberd, 1976

Subclass Prymnesiophycidae Cavalier-Smith, 1986 Order Prymnesiales Papenfuss, 1955

Family Prymnesiaceae O.C. Schmidt, 1931

Genus Hyalolithus Yoshida et al., 2006

Type species Hyalolithus neolepis Yoshida et al., 2006

Hyalolithus tumescens sp. nov.

(Figs 2-4)

Derivation of name. With reference to the swollen structure seen in proximal view; tumescens $(\mathrm{L}$.) $=$ swelling.

Diagnosis. A fossil species of Hyalolithus characterized by scales with an indentation on one side of the central mound in distal view and an off-centre swelling seen in proximal view.

Holotype. Distal view of scale (Fig. 2: 4). Slide deposited in the National Science Museum, Tokyo. England Finder Reference: R26/3. Paratype. Distal view of scale (Fig. 2: 8). Slide (same as holotype) deposited in the National Science Museum, Tokyo. England Finder Reference: T24/3.

Material. 38 scales (21 in the SEM, 17 in the LM) from Barbados, 12 scales ( 7 in the SEM, 5 in the LM) from California. In total, 33 and 307 images were taken in the SEM and LM, respectively.

Type locality. Chalky Mount, Barbados.

Age. middle Eocene.

Description. Solid siliceous scales, circular to elliptical in shape. On distal side, scale with prominent marginal rim and perforated central mound, separated by narrow to wide hyaline area. Perforated area consists of about 30-150 circular to elliptical openings (pores) of variable size. One side of central mound with indentation and pitlike depression, always on long axis. On proximal side, perforated central area surrounded by hyaline margin. Swelling (corresponding to pit-like depression on distal side), perforated around the base, situated on long axis.

Dimensions. Scales 7.0-11.0 $\mu \mathrm{m}$ long, $5.5-9.4 \mu \mathrm{m}$ wide. Openings $0.2-1.2 \mu \mathrm{m}$ long. Swelling $0.9-2.1 \mu \mathrm{m}$ in diameter.

Occurrence. Also found in samples from Springfield (Barbados) and Kellogg Shale (California) in this study.

Remarks. The siliceous scales of the type species Hyalolithus neolepis, like those of $H$. tumescens sp. nov., are solid, circular to elliptical in shape, with a prominent marginal rim and perforated central mound, separated by a narrow to wide hyaline area. However, the scales of $H$. neolepis are generally much smaller in size $(2.9-7.9 \mu \mathrm{m}$ long, 2.8-7.0 $\mu \mathrm{m}$ wide), with more (about $45-350)$ but smaller $(0.1-0.3 \mu \mathrm{m}$ long) openings. A small pit-like depression occurs rarely between the two central mounds on the distal side, with a corresponding centrally placed swelling $(0.5-$ $0.7 \mu \mathrm{m}$ in diameter) on the proximal side. The swelling is perforated seemingly all over the surface, whereas that of $H$. tumescens is perforated only near the base. We chose the word 'swelling' because it is part of the perforated surface not a separate structure and is thus unlike the hollow imperforate tube as seen in the exothecal coccoliths of Syracosphaera pulchra Lohmann.

\section{Discussion}

The siliceous microfossils (notably radiolaria, diatoms and sponge spicules) in the Barbados deposits were studied over 150 years ago by Ehrenberg $(1847 a, b)$ and Greville (1861-66) and by many subsequent workers. The fossils were mostly attributed to a sedimentary layer called the Oceanic series (also Oceanic deposits or Oceanic beds), which was either calcareous, siliceous or a mixture of the two (Harrison \& Jukes-Browne 1890). The radiolarian ooze-like siliceous sediments were thought to have been deposited in a deep basin, about 3600-7300 $\mathrm{m}$ deep, and were considered to be Pliocene or Pleistocene in age (Harrison \& JukesBrowne 1890; Jukes-Browne \& Harrison 1892). Senn (1940) discussed the stratigraphic sequence and dated them using foraminifera, considering the 'Oceanic Formation' to be late Eocene to early Oligocene in age. An Eocene assignment was also given by Hanna \& Brigger (1964) who studied the diatoms from Joe's River, with Holmes \& Brigger (1979) later refining the date to the Eocene-Oligocene boundary and giving an age of middle Eocene for the Conset and Cambridge localities based on radiolarians. Our own observations on some of the Barbados deposits (Chalky Mount, Springfield, Cambridge Estate) suggest that the assemblages belong to the Craspedodiscus oblongus Zone of the middle Eocene, since they contain Craspedodiscus oblongus (Greville) Grunow, C. ellipticus (Greville) Gombos and Tubaformis unicornis Gombos, characteristic middle Eocene diatoms (Gombos 1983; Fenner 1985). The absence or rarity of pennates in the samples suggests deposition in an offshore environment.

The siliceous microfossils of the Kellogg Shale in northern California have been studied since the pioneering works on radiolarians (Clark \& Campbell 1942), diatoms (Kanaya 1957) and silicoflagellates (e.g. Mandra 1968). These studies quickly established a late Eocene age for the sediments, but this has since been refined to the middle Eocene (see discussion in Barron et al. 1984). Characteristic middle Eocene diatoms from the Kellogg Shale observed in this study include Craspedodiscus ellipticus and Triceratium inconspicuum Greville var. trilobata Fenner. These sediments were deposited offshore, not near the coast, as benthic diatom taxa (e.g. Paralia Heiberg) are scarce, while brackish and freshwater taxa (e.g. Hantzschia Grunow) may be modern contaminants (Barron et al. 1984).

The finding of Hyalolithus tumescens was timely and quite fortuitous, since at the time we were investigating the morphological diversity and distribution of Hyalolithus and Petasaria in living communities (Jordan et al. 2016) and also searching for Macrora species in Eocene samples. However, the discovery of fossil

Fig. 1. 1-7. Hyalolithus neolepis Yoshida et al. SEM. Seto-29, Seto Inland Sea, Japan: 1, a collapsed cell revealing the variability in scale dimensions and shape, with most scales in proximal view; 2 , scales in distal view, with small circular scale, centre left; $\mathbf{3}$, two scales in distal view, showing large difference in size; $\mathbf{4}$, distal view of scale on left-hand side showing small depression (arrowhead); 5 , proximal view of scale on left-hand side showing small swelling, off centre (arrowhead); 6, proximal view of scale showing a swelling, off centre (arrowhead); 7 , scales in distal and proximal views, with one in distal view showing off-centre indentation (arrowhead). Scale bars $1 \mu \mathrm{m}(3-6)$ or $2 \mu \mathrm{m}(1-2,7)$. 

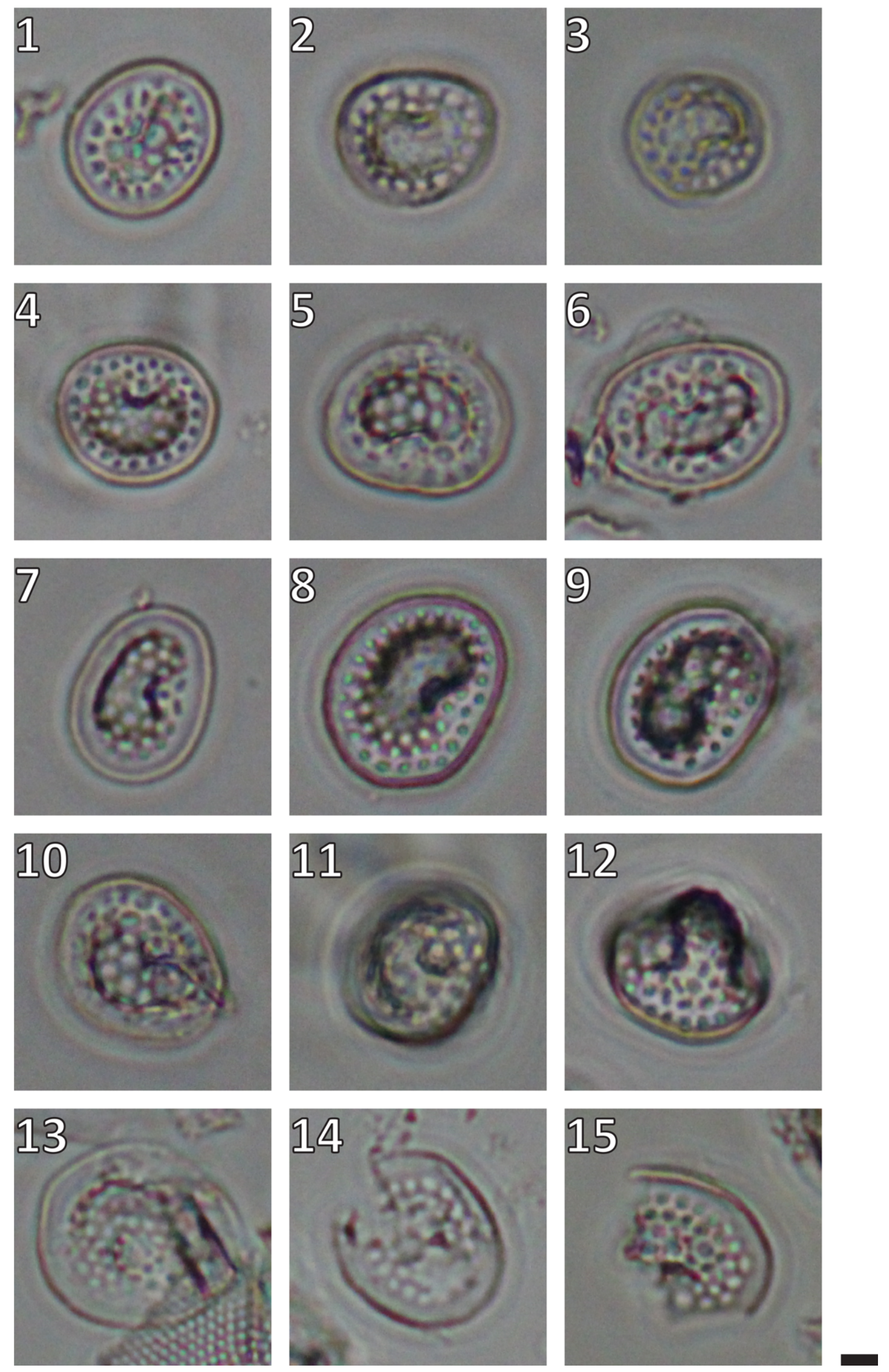

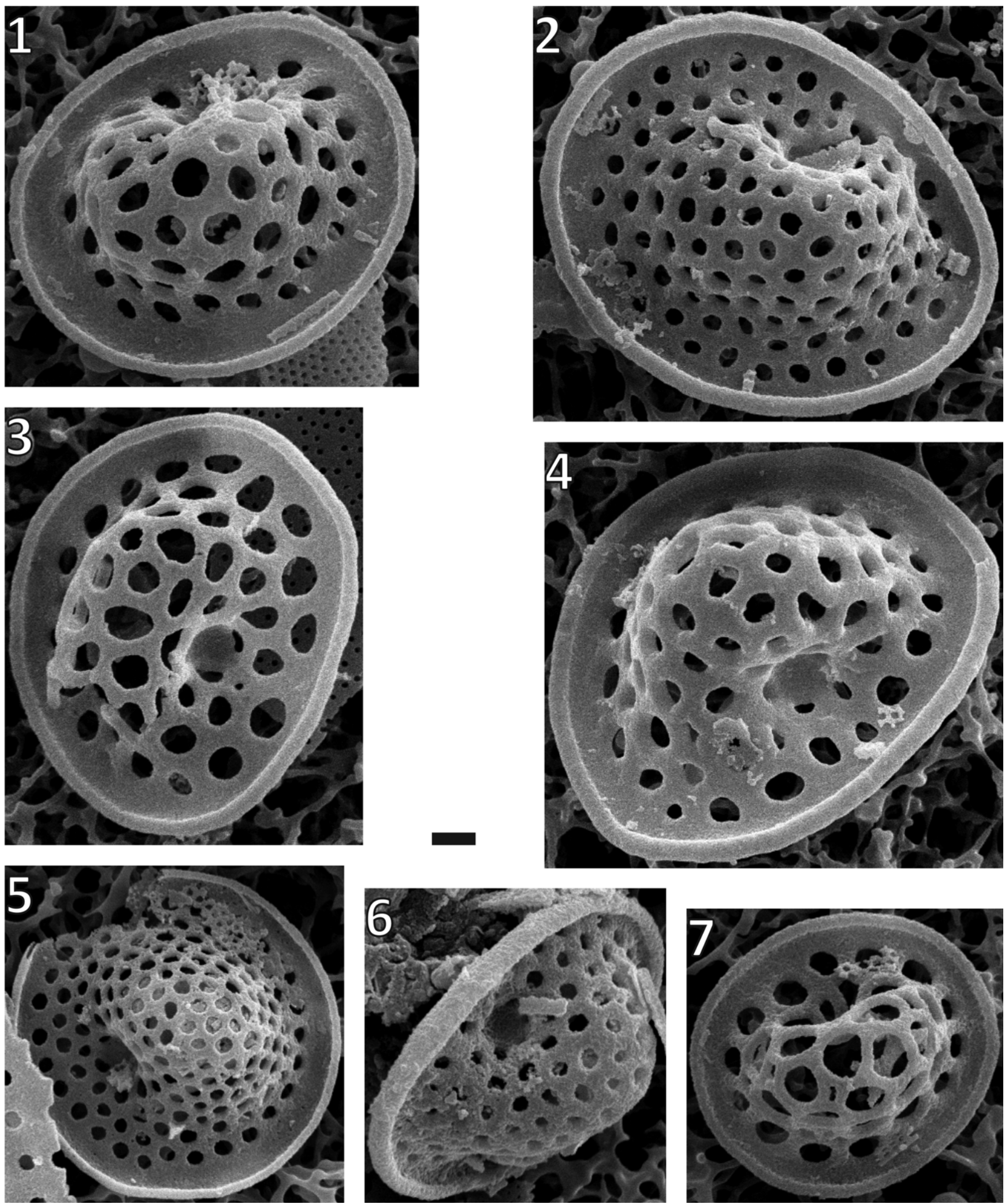

Fig. 3. 1-7. Hyalolithus tumescens sp. nov. SEM: 1-3, 7 (Chalky Mount, Barbados AM 22 A), 4-6 (Springfield, Barbados). 1-7, Distal view, showing indentation $(1-2,5,7)$ and pit-like depression $(3-4,6)$ on one side of the central mound. Note variable size and number of openings, as well as the width of the marginal hyaline area. Scale bar $1 \mu \mathrm{m}$.

Fig. 2. 1-15. Hyalolithus tumescens sp. nov. LM: 1-12 (Chalky Mount, Barbados AM 22A); 13-15 (Kellogg Shale CD-11). Note nearly circular forms (1$4,13)$ or elliptical forms $(6-10)$, indentation on long axis side (4-10) and central mound (11-12). 4 is the holotype and $\mathbf{8}$ is the paratype. All scales in distal view. Scale bar $2 \mu \mathrm{m}$. 

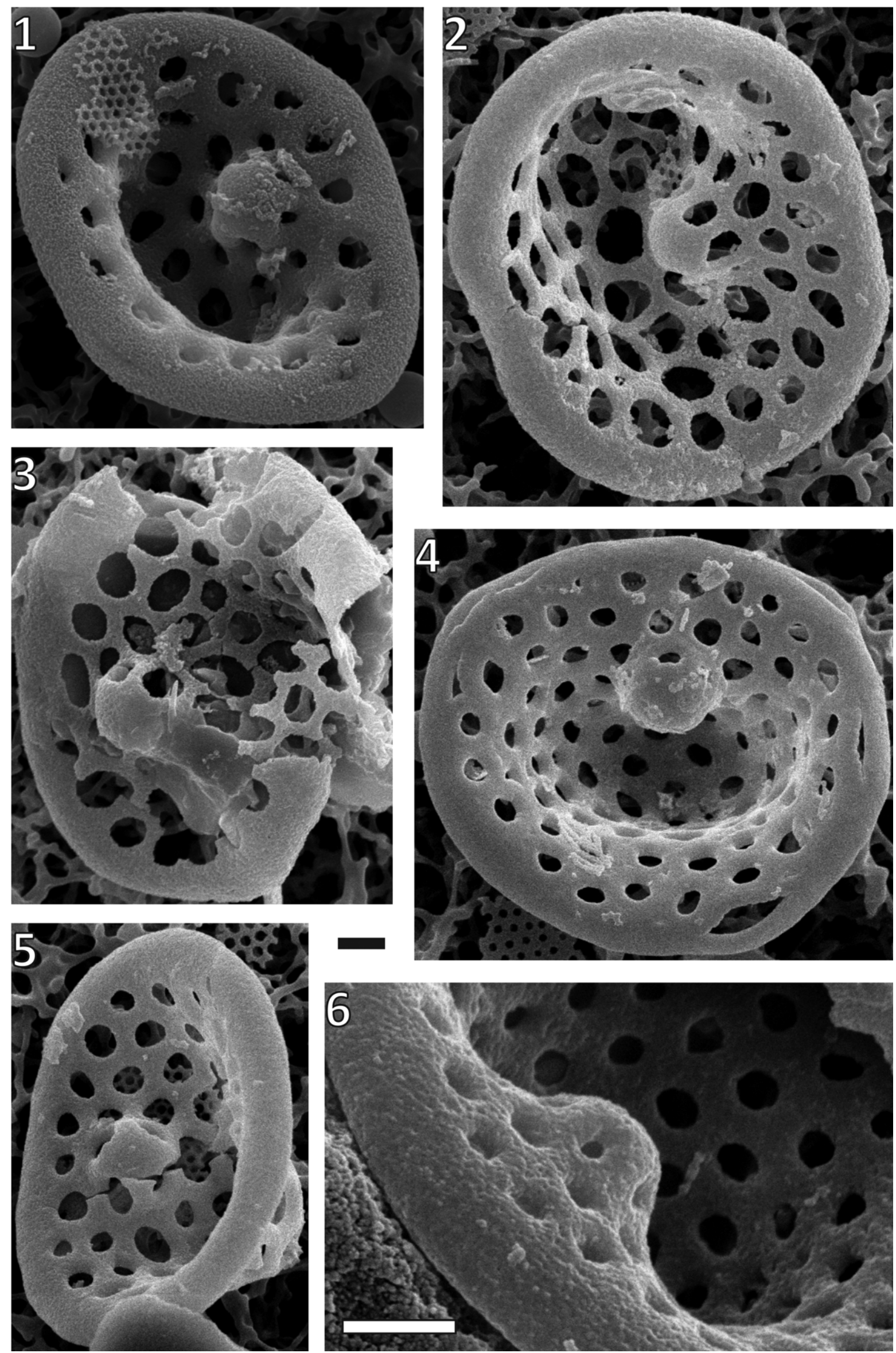
Hyalolithus scales raises several important questions: (1) why have they not been reported before? (2) Can we expect to find scales in younger or older deposits? (3) What conditions favour the preservation of Hyalolithus scales?

Given their small size, it is possible they were overlooked by previous workers using the light microscope, or simply ignored by those studying diatoms or misidentified as Macrora. In this study, H. tumescens was always found in co-existence with Macrora barbadensis (Deflandre) Bukry and M. najae Bukry, although Macrora is sometimes found in middle Eocene samples (e.g. Cambridge Estate, Barbados and Bet Guvrin Area, Israel) in which Hyalolithus is seemingly absent.

Preliminary investigations of Oligocene-Miocene sediments containing Macrora stella (Azpeitia) Hanna and stella-like forms have not yielded any Hyalolithus. However, one late Miocene age sample from Caltanissetta in Sicily did possess Hyalolithus scales and will be the subject of a separate paper. As for specimens in older sediments, it is quite possible that they exist; however, this would require a much more rigorous search of other samples using the SEM than has been carried out to date.

Neither Macrora nor Hyalolithus has been observed in middle Eocene sediments from temperate to polar regions (e.g. Norwegian Sea, Arctic Ocean or Southern Ocean), suggesting they are restricted to middle-low latitudes. The true affiliation of Macrora is still unknown, but our findings so far suggest it is not a haptophyte scale, but may have affinities with modern filose amoebae such as Pinaciophora Greeff. It is likely that further discoveries of fossil Hyalolithus will be rare, since tropical marine coastal sediments are poorly preserved and Hyalolithus never forms large populations in modern oceanographic settings.

\section{Conclusions}

The discovery of Hyalolithus tumescens sp. nov. in middle Eocene sediments has, for the first time, provided evidence of the fossil record of the Prymnesiales and opens up the possibility of finding other siliceous haptophyte scales in sediments of similar or different ages. Both species of Hyalolithus are associated with warm to temperate waters, so fossil scales may be found in tropical to temperate siliceous sediments, particularly those with good preservation. The presence of a swelling on the proximal side of the scale in both living and fossil Hyalolithus species suggests that this may be a common trait of the genus. Despite their overall similarity, the scales of the fossil specimens are sufficiently different from those of modern specimens to warrant their separation at the species level.

\section{Acknowledgements and Funding}

We would like to thank Friedel Hinz, John Barron and the late Frithjof Sterrenburg for providing the outcrop samples used in this study, and the captain and crew of the research and training vessel Bosei-maru of Tokai University for their help during the 2008 cruise to the Seto Inland Sea. We would like to thank Jeremy Young, Alan Lord and two anonymous reviewers for their valuable comments.

\section{Scientific editing by Alan Lord}

\section{References}

Abe, K., McCartney, K., Fukunaga, Y., Narita, H. \& Jordan, R.W. 2015 Silicoflagellates and ebridians from the Seto Inland Sea and Kuroshio, including the description of Octactis pulchra var. takahashii var. nov. Journal of Nannoplankton Research, 35, 111-128.

Barron, J.A., Bukry, D. \& Poore, R.Z. 1984. Correlation of the middle Eocene Kellogg Shale of northern California. Micropaleontology, 30, 138-170.
Cavalier-Smith, T. 1986. The kingdom Chromista: origin and systematics. Progress in Phycological Research, 4, 309-347.

Clark, B.L. \& Campbell, A.S. 1942. Eocene Radiolarian Faunas from the Mt. Diablo Area, California. Geological Society of America, Special Papers, 39, 1-112.

Edvardsen, B., Eikrem, W., Throndsen, J., Sáez, A.G., Probert, I. \& Medlin, L.K 2011. Ribosomal DNA phylogenies and a morphological revision provide the basis for a revised taxonomy of the Prymnesiales (Haptophyta). European Journal of Phycology, 46, 202-228.

Ehrenberg, C.G. 1847a. Über eine halibiolithische, von Herrn R. Schomburgk entdecke, vorherrschend aus mikroskopischen Polycystinen gebildete, Gebirgsmasse von Barbados. Monatsberichte der Königliche Preussischen Akademie der Wissenschaften zu Berlin, 1846, 382-385.

Ehrenberg, C.G. 1847b. Über die mikroskopischen kieselschaligen Polycystinen als mächtige Gebirgsmasse von Barbados und über das Verhältniss der aus mehr als 300 neuen Arten bestehenden ganz eigenthümlichen Formengruppe jener Felsmasse zu den jetzt lebenden Thieren und zur Kreidebildung. Eine neue Anregung zur Erforschung des Erdlebens. Monatsberichte der Königliche Preussischen Akademie der Wissenschaften zu Berlin, 1847, 40-60.

Fenner, J. 1985. Late Cretaceous to Oligocene planktic diatoms. In: Bolli, H.M., Saunders, J.B. \& Perch-Nielsen, K. (eds) Plankton Stratigraphy, 2. Cambridge University Press, Cambridge, 713-762.

Gombos, A.M., Jr 1983. Middle Eocene diatoms from the South Atlantic. In: Ludwig, W.J., Krasheninnikov, V.A. et al. (eds) Initial Reports of the Deep Sea Drilling Project, 71. US Government Printing Office, Washington, DC, $565-581$.

Green, J.C., Hibberd, D J \& Pienaar, R.N. 1982. The taxonomy of Prymnesium (Prymnesiophyceae) including a description of a new cosmopolitan species, $P$. patillifera sp. nov., and further observations on P. parvum N. Carter. British Phycological Journal, 17, 363-382.

Greville, R.K. 1861-66. Descriptions of new and rare diatoms. Transactions of the Microscopical Society of London, new series. A series of 20 papers published in vols 9-14.

Hanna, G.D. \& Brigger, A.L. 1964. Some fossil diatoms from Barbados. Occasional Papers of the California Academy of Sciences, 45, 1-27.

Harrison, J.B. \& Jukes-Browne, A.J. 1890. The Geology of Barbados. Bennett Brothers, Salisbury, UK

Hibberd, D.J. 1976. The ultrastructure and taxonomy of the Chrysophyceae and Prymnesiophyceae (Haptophyceae): a survey with some new observations on the ultrastructure of the Chrysophyceae. Botanical Journal of the Linnean Society, 72, 55-80.

Holmes, R.W. \& Brigger, A.L. 1979. The marine fossil genus Entogonia Greville - a review. Bacillaria, 2, 155-214.

Jordan, R.W., Abe, K. et al. 2016. Observations on the morphological diversity and distribution of two siliceous nannoplankton genera, Hyalolithus and Petasaria. Micropalaeontology, 61, 439-455.

Jukes-Browne, A.J. \& Harrison, J.B. 1892. The Geology of Barbados. Part II. The Oceanic Deposits. Quarterly Journal of the Geological Society of London, 48 170-226, http://doi.org/10.1144/GSL.JGS.1892.048.01-04.16

Kanaya, T. 1957. Eocene diatom assemblages from the Kellogg and 'Sidney' shales, Mt. Diablo area, California. The Science Reports of the Tohoku University, Sendai, Japan, 2nd Series (Geology), 28, 27-124.

Mandra, Y.T. 1968. Silicoflagellates from the Cretaceous, Eocene, and Miocene of California, U.S.A. California Academy of Science, Proceedings, 36, 231-277.

Moestrup, Ø. 1979. Identification by electron microscopy of marine nanoplankton from New Zealand, including the description of four new species. New Zealand Journal of Botany, 17, 61-95.

Papenfuss, G.F. 1955. Classification of the algae. In: Kessel, E.L. (ed.) A Century of Progress in the Natural Sciences, 1853-1953. California Academy of Sciences, San Francisco, USA, 115-224.

Patil, S., Mohan, R., Shetye, S., Gazi, S. \& Jafar, S.A. 2014. Prymnesium neolepis (Prymnesiaceae), a siliceous Haptophyte from the southern Indian Ocean. Micropaleontology, 60, 475-481.

Patil, S., Mohan, R., Gazi, S., Shetye, S. \& Jafar, S.A. 2015. Petasaria heterolepis (Prymnesiaceae) from the Southern Indian Ocean. Micropaleontology, 61, 171-176.

Pienaar, R.N. 1980. Observation on the structure and composition of the cyst of Prymnesium (Prymnesiophyceae). Proceedings of the Electron Microscopy Society of Southern Africa, 10, 73-74.

Schmidt, O.C. 1931. Algen 1925-1927. Mit Nachträgen aus den Jahren 1914 bis 1924. Just's Botanischer Jahresbericht, 55, 20-312.

Senn, A. 1940. Paleogene of Barbados and its bearing on history and structure of Antillean-Caribbean region. American Association of Petroleum Geologists Bulletin, 24, 1548-1610.

Yoshida, M., Noël, M.-H., Nakayama, T., Naganuma, T. \& Inoue, I. 2006. A haptophyte bearing siliceous scales: ultrastructure and phylogenetic position of Hyalolithus neolepis gen. et sp. nov. (Prymnesiophyceae, Haptophyta). Protist, 157, 213-234. 